Article

\title{
Advances in Research on Technological, Pedagogical, Didactical, and Social Competencies of Preservice TCFL Teachers
}

\author{
Mohamed Oubibi ${ }^{1, *}\left(\mathbb{D}\right.$, Wei Zhao ${ }^{2, *}$, Yue Wang ${ }^{3}$, Yueliang Zhou ${ }^{1,4}$, Qiang Jiang ${ }^{2}$, Yue $\mathrm{Li}^{2}$, Xiaoqing $\mathrm{Xu}^{2}$ and \\ Lifang Qiao ${ }^{2}$ \\ 1 College of Teacher Education, College of Education and Human Development, Zhejiang Normal University, \\ Jinhua 321000, China; zhouyl@zjnu.cn \\ 2 School of Information Science and Technology, Northeast Normal University, Changchun 130024, China; \\ jiangqiang@nenu.edu.cn (Q.J.); liy116@nenu.edu.cn (Y.L.); xuxq271@nenu.edu.cn (X.X.); \\ 18712762311@163.com (L.Q.) \\ 3 College of Humanities, Northeast Normal University, Changchun 130024, China; yuewang202122@163.com \\ 4 Key Laboratory of Intelligent Education Technology and Application of Zhejiang Province, \\ Zhejiang Normal University, Jinhua 321004, China \\ * Correspondence: liby478@nenu.edu.cn (M.O.); zhaow577@nenu.edu.cn (W.Z.)
}

check for updates

Citation: Oubibi, M.; Zhao, W.; Wang, Y.; Zhou, Y.; Jiang, Q.; Li, Y.; Xu, X.; Qiao, L. Advances in Research on Technological, Pedagogical, Didactical, and Social Competencies of Preservice TCFL Teachers. Sustainability 2022, 14, 2045 https://doi.org/10.3390/ su14042045

Academic Editors: María del Mar Molero Jurado, África

Martos Martínez

and Ana Belén Barragán Martín

Received: 26 December 2021

Accepted: 7 February 2022

Published: 11 February 2022

Publisher's Note: MDPI stays neutral with regard to jurisdictional claims in published maps and institutional affiliations.

Copyright: (C) 2022 by the authors. Licensee MDPI, Basel, Switzerland. This article is an open access article distributed under the terms and conditions of the Creative Commons Attribution (CC BY) license (https:// creativecommons.org/licenses/by/ $4.0 /)$.

\begin{abstract}
With the development of China, learning the Chinese language has received more and more attention from international students. Teaching Chinese as a foreign language (TCFL) is crucial for spreading Chinese culture and promoting cultural exchanges. In recent years it has become the focus of attention of many scholars, and the heterogeneous cultural backgrounds and diverse language needs of learners determine that TCFL should promote the development of students' intercultural communication competence in language practice with the use of educational technology. In this study, 82 preservice teachers as an experiment group and 64 preservice teachers as a control group participated in this study; this research aims to improve the quality and level of TCFL, using innovative teaching tools as a means to target preservice TCFL teachers and create a teachinglearning design strategy based on the smart teaching tools Moso Teach (MT) and Rain Classroom (RC). The findings from this research show the importance of the use of smart teaching tools and the improvement of preservice teachers during the experiment compared to preservice teachers with traditional methods. This paper answers the following questions: (1) How to improve preservice TCFL teachers' competencies by integrating smart teaching tools into their learning process? (2) How to integrate technological, pedagogical, didactic, and social competencies into preservice teachers' daily teaching CFL?
\end{abstract}

Keywords: preservice teachers; teaching Chinese as a foreign language (TCFL); Moso Teach (MT); technological, pedagogical, didactic and social competencies; Rain Classroom (RC); information and communications technology (ICT)

\section{Introduction}

During the last decade Chinese has emerged as an increasingly important language, taught and learned as an international language around the world [1-3]. In 2018 492,200 international students from 196 countries/regions attended Chinese tertiary institutions, and almost half of them were learning Chinese as an additional language [4,5]. While students that study abroad are assumed to have abundant opportunities to immerse themselves in the target culture and use the target language of the host community [6-8], identity can influence both the quality of language learning experiences and learners' strategic efforts in study abroad settings; several studies have examined the identity of study abroad learners and its complex relationship with strategic language learning [9-13]. However, in these studies, the voice of international students studying abroad in China has rarely been heard to any great extent [14-17]. 
The concepts and methods of teaching Chinese as a foreign language lag behind the developments of the times and cannot meet the development needs of teaching Chinese as a foreign language. In terms of its nature, the teaching of Chinese as a foreign language is the Chinese language taught by Chinese teachers to international students [17]. Therefore, to ensure the effectiveness of teaching, teaching Chinese as a foreign language must respect the heterogeneous cultural background of international students, grasp the learning characteristics of Chinese as a language, and focus on cultivating students' cross-cultural communication skills in language practice. Cultivating communicative competence, emphasizing interactive application, emphasizing the laws of cognition, recognizing multiculturalism, and highlighting the main body of students are the basic requirements for teaching Chinese as a foreign language [18,19].

The use of mobile digital media, which primarily comprises smartphones and tablets, has pervaded various elements of learning as information technology and communication networks. Mobile learning is a new social development paradigm that aims to aid students in learning through mobile devices, and learning tools are being employed from high school classrooms to university students because of their portability and the capacity to access their content at any time [20].

WeChat is unlimited access software developed by Tencent Holdings Limited that is used by more than 94 percent of Chinese smartphone users. WeChat is currently the most popular social networking application in China [21].

Rain Classroom is a new smart teaching tool that combines WeChat and other social media platforms. Rain Classroom uses PowerPoint slideshows and WeChat to incorporate complicated information technology methodologies. When teachers use PowerPoint slideshows for teaching and students use WeChat, preclass learning, classroom teaching, and postclass revision can be integrated into the Rain Classroom teaching system. It improves the traditional teaching and learning methodologies and propels educational transformation. As a result, the widely used WeChat platform can be combined with the Rain Classroom tool to extend traditional teaching outside of the classroom, promoting proactive student learning as well as enthusiasm while improving learning outcomes [22,23].

Theoretically, in the last couple of decades the Chinese language has been increasingly taught and learned as an essential second or foreign language both within and outside China. Commensurate with this considerable growth in learners of the language, studies have yielded important insights into critical issues concerning the Chinese language teaching pedagogy [24-26], language policy and planning [26,27], language testing [28], and Chinese language teachers' education and professional development [29-33].

In this case, international students studying the Chinese language and Chinese preservice TCFL teachers, universities, schools related to teaching CFL, and companies working in the field of developing the software, platforms, and specialized materials to be used in the teaching-learning process by designing, testing, modifying, approving, and evaluating a design teaching system can integrate many aspects related to the use of technology, pedagogy, didactic, and social skills by teachers $[17,34]$.

This paper aims to provide a systematical analysis of preteacher TCFL integration of technological, pedagogical, didactical, and social competencies with smart teaching tools into the classroom. This study has the following questions:

- How to improve preservice TCFL teachers' competencies by integrating smart teaching tools into their teaching processes?

- How to integrate technological, pedagogical, didactic, and social competencies into preservice teachers' daily teaching CFL?

\section{Literature Review}

Since its opening in the late 1970s, China has worked tirelessly to improve indigenous people's English skills to enable their engagement with other countries and to promote participation in globalization [35]. However, in the last decade the dominance of the English language has been challenged by the growing importance of Chinese, which is increasingly 
being taught as an essential second or foreign language in and outside of China [3]. China's government has increased its international programs to attract 500,000 foreign students by 2020 [36], about three times the '140,000 foreign students' in 2005. The first Confucius Institute opened in South Korea in 2004, and the first World Chinese Congress was held in Beijing in 2005. By December 2015 1,500 Confucius Institutes and classrooms were open in 135 countries, with over 1.39 million students learning Chinese. Increased government investment has aided the significant expansion of Chinese as a second or foreign language (CSL/CFL) education and rising research initiatives addressing crucial issues connected to the teaching of Chinese as a second or foreign language (TCSL/TCFL) [1].

The major setback in learning a language is remembering and constructing words using new sounds, rhythms, and intonations to convey thoughts and intentions smoothly. In other words, the hardship in learning a foreign language is gradually developing the materials of a particular language $[37,38]$. Thus, a practical approach to learning a language has become an essential discussion among researchers. Furthermore, every learner has different capabilities, influenced by their background, personality, motivation, learning style, and purpose. Numerous studies have tried to resolve the learning challenges from different perspectives. They include steps to overcome anxiety [39,40], motivation to increase performance [41,42], better learning strategies [43-45], improvised speaking methods [40,46], and improving intonation perception [47]. Some studies have also investigated the difficulties experienced by learners in technology-aided learning $[46,48,49]$.

\subsection{Teaching Chinese as a Foreign Language}

Chinese has become more widely taught and acquired as a second or foreign language both within and beyond China over the last few decades. Studies on the cognitive and sociocultural aspects of Chinese language learning [2,50], Chinese language teaching pedagogy [24,26], language policy and planning [27,51], language testing, and Chinese language teacher education and professional development $[32,33,52]$ have all benefited from this significant increase in learners of the language. Theoretical discussions on the acquisition of Chinese as a second or foreign language (CSL/CFL) have benefited from research findings on CSL/CFL acquisition by verifying, questioning, or proposing modifications to current L2 theories and models. The outcomes of research on CSL/CFL teachers have broadened the discourse on teacher education and recognized particular issues posed by Confucian teaching and learning ideologies. Because Chinese is a typologically distinct language from Western languages, research into Chinese learning can considerably develop and test L2 theories $[53,54]$.

\subsection{Teacher Competencies}

The capacity to accomplish something successfully or efficiently is a competency. Competencies are a lot more than just talents. Competencies combine skills, talents, and knowledge specific to an activity. Competencies comprise three components: knowledge, abilities, and skills. New types of education that assist students' capacity building, such as using technology to enhance critical thinking, problem solving, and communication skills, are in high demand [55]. Although many schools have substantial access to computers and other digital infrastructure the pedagogical application of instructional technology differs [56]. Preservice teachers' experience with technology throughout teacher education, both via their usage and through seeing teacher educators' use, is a critical component in developing professional digital competence and attitudes, as [57] discovered. The degree to which teacher educators employ technology in their classrooms may thus directly impact their students' attitudes and dispositions toward incorporating technology into their future classrooms. However, there is reason to assume that technology is employed less frequently than in primary schools [58]. Furthermore, analyses of Chinese teacher education curriculum materials show that digital competence and technology use are not successfully integrated into the curriculum, neither at the topic level nor the program level [17]. 


\subsection{Smart Teaching and Learning System}

With the increasing influence of information and communications technology (ICT), academic interest in understanding the potential impact of technology on education has grown $[59,60]$. Prior research has shown that technology-assisted teaching improves learner engagement and learning outcomes [61-64]. Furthermore, as technology advances and becomes more affordable, various educational devices have been developed to give students more learning opportunities [65]. Despite this, research has found that instructors, particularly preservice teachers, do not use technology efficiently and thoroughly in their classrooms. This could be due to a lack of engaging opportunities, professional development, and supportive support for implementing the change in teachers' intentions to use technology. Teachers may be apprehensive about the change in instruction, as [66] pointed out, because the effects of the change are unpredictable. Given that teachers' favorable opinions and beliefs have a significant role in the success and efficacy of deploying educational technology [67], it is critical to understand what factors drive or hinder teachers acceptance of educational technology [68]. As a result, specific interventions can increase teachers' desire to use instructional technology in their classrooms. For this purpose, there has been an increase in studies evaluating the adoption and use of instructional technology by English as a second/foreign language (L2 English) teachers in various educational and cultural contexts, such as China [69], Korea [53], and Turkey [70]. Although such research reveals that L2 English instructors' attitudes toward technology use are positive, few studies have focused on the impact and implications of ICT on L2 Chinese teaching, except for a few studies concentrating on the impact and implications of ICT on L2 Chinese teaching. Furthermore, cross-cultural studies have demonstrated that cultural differences may influence people's technology usage. As a result, additional contextualized research is required to enable teachers from various backgrounds to use technology to its full potential, mainly because there is general agreement that educational technology may benefit the L2 learning and teaching field [67]. Meanwhile, more than 10,000 preservice L2 Chinese teachers and volunteers were recruited to support L2 teaching initiatives worldwide in 2018, according to a report released by the Confucius Institute Headquarters [2]. Given the circumstances, this study studied the factors influencing preservice L2 Chinese teachers' desire to use technology in their future classes, using a theoretical viewpoint informed by earlier technology acceptance research. Innovative learning is comprehensive e-learning in which learning resources are matched to user needs. It also enables learning delivery platforms to tailor their method, content, and delivery pace to students and the learning context, resulting in a personalized and adaptive e-learning environment [71]. Option interface of Rain classroom and in-class interaction in Figure 1.
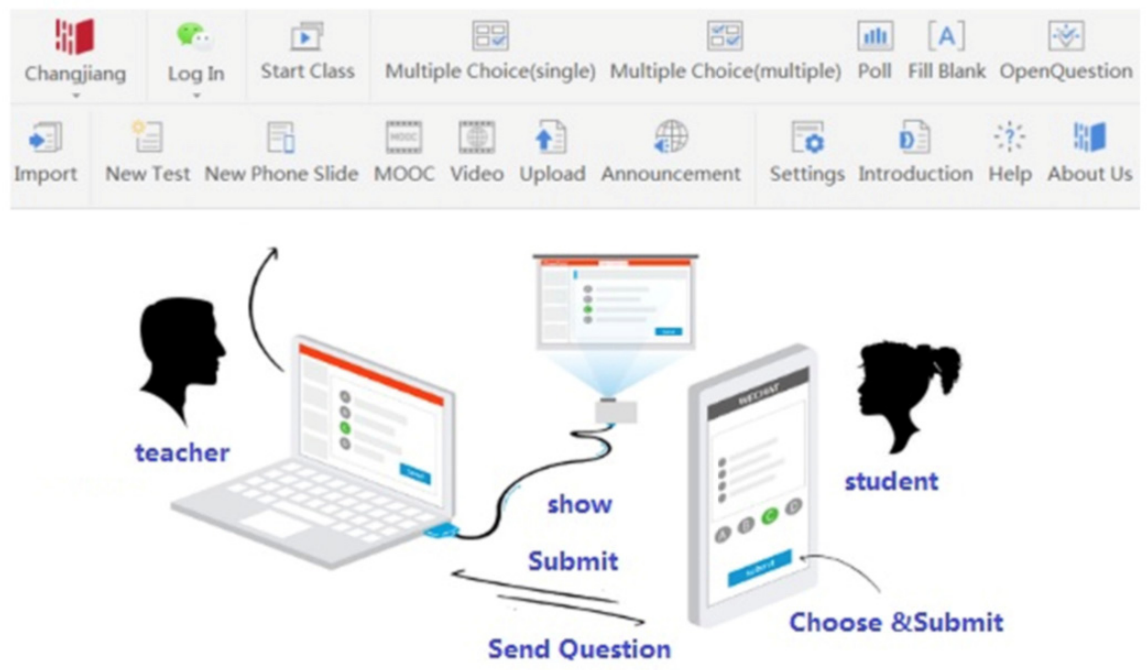

Figure 1. Options interface of Rain Classroom and in-class interaction. 
The benefits of mobile platforms, such as the WeChat application, as a languagelearning tool for Chinese as a foreign/second language (FL/L2) have sparked increased interest in recent years. WeChat, a popular mobile social networking and messaging software, enables Chinese language instructors worldwide to collaborate on a single platform for mobile-assisted language study (MALL). WeChat-supported MALL research benefits a broad group of people. Previous research has looked at how WeChat facilitates daily communication in the study abroad (SA) setting and language-learning activities, informal instruction, or tandem Chinese programs in the FL context [49,72]. Figure 2 depicts an online education model based on WeChat and Rain Classroom.

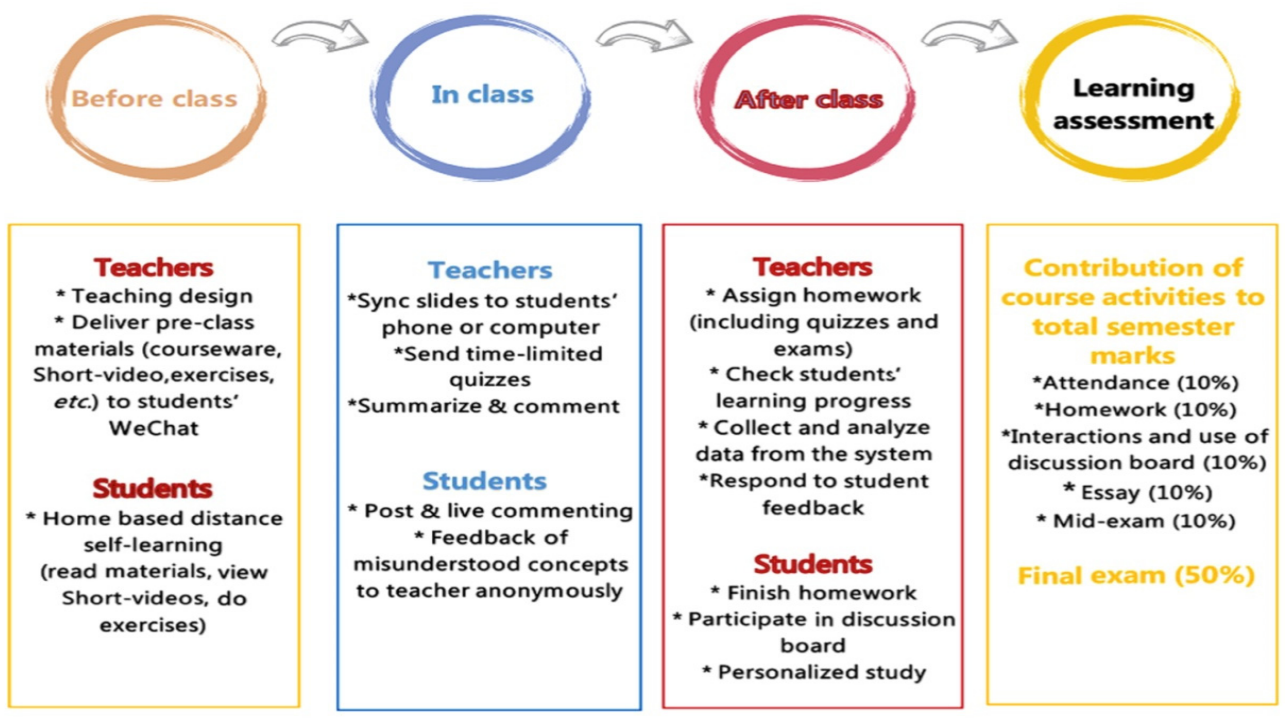

Figure 2. Online teaching module based on Rain Classroom and WeChat.

\subsection{Technological Pedagogical Content Knowledge: TPACK}

Presently, the TPACK model is one of the most prominent models of teacher knowledge for the effective use of digital technologies in teaching. However, as described above, TPACK research emphasizes several theoretical and methodical issues [73].

Although the TPACK framework can be considered as one of the most popular concepts in research on educational technology [74], it has also been criticized for its lack of conceptual clarity and specificity [75], as well as for its 'fuzzy boundaries'.

Due to the pervasive influence of computer technology on education, teachers have been increasingly integrating technological tools and resources into their instructions. In the face of such change in teaching practices, [76] proposed a theoretical construct of teacher knowledge, technological pedagogical content knowledge (TPACK), which extends from pedagogical content knowledge (PCK) [77]. When teachers apply technology to their teaching, they must understand the technology in addition to the PCK they possess beforehand.

TCFL teachers need to conceive of how to combine educational technology with classroom design to improve teaching and learning $[42,78]$. TPACK is a knowledge system that adapts to the new needs of TCFL teaching under an information technology background formed by the interaction of different knowledge bases. These knowledge systems can be developed and measurable. With the development of smart teaching tools and the updating of the classroom environment, high-quality teaching requires preservice teachers to have good teaching and knowledge ability as well as an understanding of the proper use of technical tools to assist teaching technology. Therefore, in introducing TPACK into the training process of preservice TCFL teachers, we can start with the different knowledge classification systems, improving the classroom teaching of preservice teachers with the internal factors, and promoting the development of the ability of preservice teachers [17]. 


\subsection{Preservice Teachers' New Competency Framework}

According to the new competency framework with four competencies, preservice teachers who master teaching Chinese to international students must develop different competencies (technological, pedagogical, didactical, and social competencies). Preservice teachers need to have the ability to teach in different situations and conditions according to the environment and available materials, respecting the different knowledge and backgrounds of international students during teaching inside or outside China [17].

Preservice TCFL teachers have to be able to use and adapt to different technologies in their teaching-learning process as well as apply adequate pedagogy in adequate time and place; furthermore, didactics is an art with which to understand subjects in addition to the knowledge of explanatory frameworks that organize and connect ideas in a social environment with intercultural experience [17].

Figure 3 shows the new competency framework of preservice TCFL teachers, based on technological, pedagogical, didactic, and social competencies.

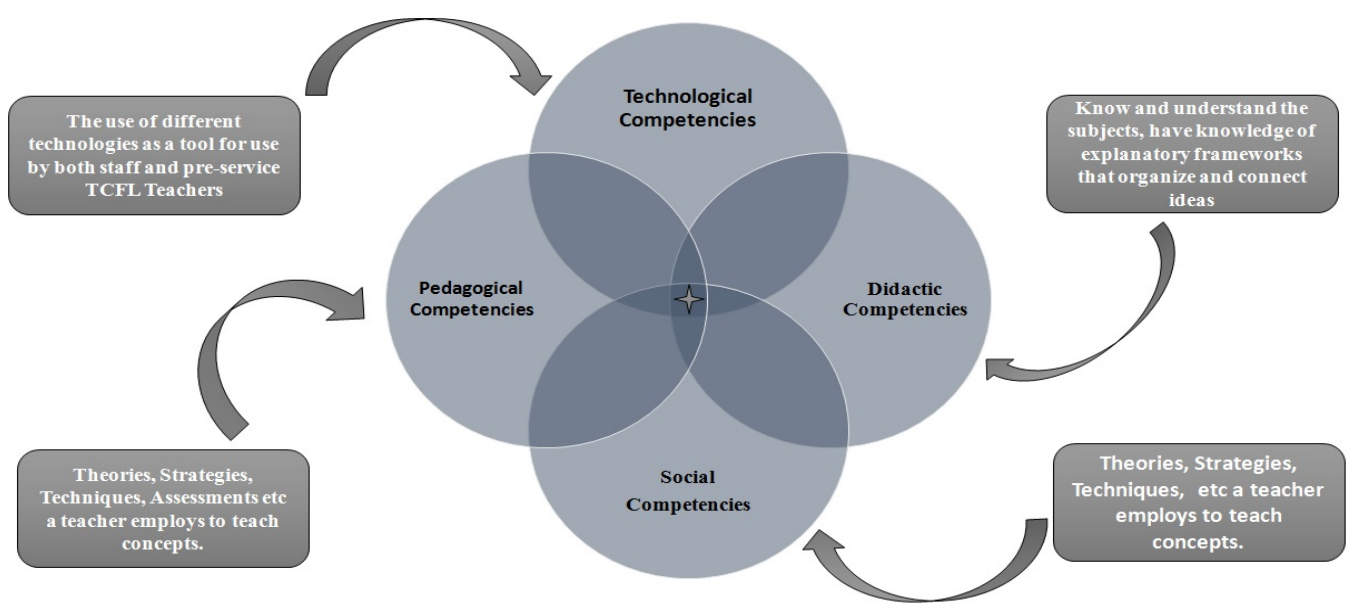

Figure 3. Preservice teachers' new competency framework.

The preservice teachers' new competency framework aims to explain how preservice teachers will adopt new and different skill-based competencies with the use of different teaching tools and by understanding the subject, knowledge, theories and strategies, and assessments to teach; the star in the middle is the fruit of mixing different competencies [17].

Technological competencies can be similar to TK in TPACK and more; they can allow a preservice teacher to be experienced in teaching and online learning as well as have the ability to utilize the different uses of multimedia, available hardware, and software, participate in activity in online discussion, communication, report, and live classroom. Technological competencies can help preservice teachers to use a variety of software, such as Word, PowerPoint, Excel, databases, spreadsheets, statistical software, and email management skills, and to be familiar with blogs, wikis, and podcasts in addition to their use in teaching and learning to make technology a simple tool with which to manage the adequate strategy and methodology for teaching a class [79].

Pedagogical competencies are the same as PK in TPACK but with different modifications in our design to be adapted to our needs, insofar as helping preservice teachers to have classroom management skills, develop and maintain their educational process, and have a better understanding of the conceptions of the subject, as well as the learning and teaching implications. It also allows preservice teachers to manage different group activities and open engaging and rich discussion between teachers and students as well as between students, reflecting teaching practices and identifying how learning outcomes can be improved. Designing effective learning can also create rich environments with ICT support and transparency in the teaching process, prepare work and lesson notes using ICT, and allow teachers to access student performance in the classroom with different conducted activities [17,80,81]. 
Preservice teachers can use didactic competencies to learn how to convey content, design materials and tools that adapt smart teaching or ICT to students, and make judgments about how students will interact and which tools will be appropriate for each type of interaction. Preservice teachers can also plan student support during the teaching and learning process, use ICT as a didactical tool in the classroom, decide on methodologies that are appropriate for students' prior knowledge and experience, design feedback and evaluation, create activities that are related to specific goals, and coach and support students in their decision-making processes [42,82].

Social competencies enable teachers to demonstrate good social skills while also demonstrating knowledge. They also enable teachers to provide students with continuous and positive constructive feedback to encourage them to participate in created activities with a high level of motivation [42]. It can enable teachers to provide students with equal opportunities to participate in collaborative activities, create a trusting environment for intercultural communication, and promote communication between students through the use of large and small group activities, as well as promote collaboration among students and assist them in the acquisition of collaboration skills by providing opportunities to demonstrate teamwork and leadership responsibility [17].

\section{Method}

\subsection{Participants}

The participants of this study were 82 preservice teachers as the experiment group and 64 preservice teachers as a control group. There were 69 females and 13 males for the EG and 55 females and 9 males for the CG. The participants' ages ranged from 18 to + 21 years; the mean age of the participants was $19.76(\mathrm{SD}=0.779)$.

Participants were randomly invited to participate in the study, and only preservice teachers majoring in teaching Chinese as a second language attended classes during one semester (18 weeks) to develop their technological, pedagogical, didactic, and social competencies; the control group took classical classes with traditional teaching methods.

Table 1 show more details about months of teaching experience and language skills that preservice teachers can speak.

\subsection{Data Collection}

In the inquiry we collected data by conducting a survey for both groups (EG and CG) as well as interviews with participants using the smart teaching tools Moso Teach and Rain Classroom.

Technological competencies (TC), a 15-item, self-report measure, were used to assess the level of technological competency. The preservice TCFL teachers indicate their agreement level with five statements $(1=$ strongly disagree, $5=$ strongly agree $)$. The scale shows strong reliability in this study $(\alpha=0.91)$.

The pedagogical competency (PC) scale is a 12-item, self-report measure that determines the preservice teachers' pedagogical competency level; TCFL teachers indicate the level of their agreement with five statements $(1=$ strongly disagree, $5=$ strongly agree $)$. The Cronbach's alpha for the PC variable was $\alpha=0.85$.

The didactic competency (DC) scale is a 10-item, self-report measure to determine the level of didactic competency of the preservice teachers with five statements $(1=$ strongly disagree, $5=$ strongly agree). The scale reliability was $\alpha=0.81$.

The social competency (SC) scale is a 10-item self-report measure to determine the social competency of the preservice teachers. It was a 5-point Likert scale $(1=$ strongly disagree, $5=$ strongly agree). The internal consistency in the current study was acceptable $(\alpha=0.83)$.

Interviews were conducted with the EG from week 12 to have access to the point of view of preservice TCFL teachers with the experiment tools, teaching strategies, the development of the experiment, and how they improve the learning environment. The questionnaire helped to define preservice teacher development among the competencies of 
the study, improve any limitations in the research, and allow for significant results before the post-test and final teaching-learning model.

The smart teaching tools allow access to different data with preservice teachers activities, resource learning, learning process, interaction, evaluation, and class participation.

Table 1. Descriptive statistics.

\begin{tabular}{|c|c|c|c|c|}
\hline & Group & Attribute & Frequency & Proportion \% \\
\hline \multirow{4}{*}{ Gender } & \multirow{2}{*}{ EG } & Male & 13 & $15.85 \%$ \\
\hline & & Female & 69 & $84.15 \%$ \\
\hline & \multirow{2}{*}{ CG } & Male & 09 & $14.06 \%$ \\
\hline & & Female & 55 & $85.93 \%$ \\
\hline \multirow{6}{*}{ Age } & \multirow{3}{*}{ EG } & $18-19$ & 03 & $3.70 \%$ \\
\hline & & $19-20$ & 65 & $79.20 \%$ \\
\hline & & +21 & 14 & $17.10 \%$ \\
\hline & \multirow{3}{*}{ CG } & $18-19$ & 02 & $3.13 \%$ \\
\hline & & $19-20$ & 39 & $60.93 \%$ \\
\hline & & +21 & 23 & $35.94 \%$ \\
\hline \multirow{6}{*}{ Experience } & \multirow{3}{*}{ EG } & 0 & 25 & $30.49 \%$ \\
\hline & & $1-6$ & 46 & $56.09 \%$ \\
\hline & & +6 & 11 & $13.42 \%$ \\
\hline & \multirow{3}{*}{ CG } & 0 & 21 & $32.81 \%$ \\
\hline & & $1-6$ & 33 & $51.56 \%$ \\
\hline & & +6 & 10 & $15.63 \%$ \\
\hline \multirow{6}{*}{ Language skills } & \multirow{3}{*}{ EG } & 1 & 2 & $2.44 \%$ \\
\hline & & 2 & 67 & $81.71 \%$ \\
\hline & & 3 & 13 & $15.85 \%$ \\
\hline & \multirow{3}{*}{ CG } & 1 & 1 & $1.56 \%$ \\
\hline & & 2 & 57 & $89.06 \%$ \\
\hline & & 3 & 6 & $9.38 \%$ \\
\hline
\end{tabular}

\subsection{Procedure}

Two groups were created: an experimental group $(E G, N=82)$ to participate in our experiment and a control group $(C G, N=64)$ to attend traditional classes as in previous years, without smart teaching tools.

The development of preservice TCFL teachers competencies has a different aspect of respecting during the teaching-learning process, and preservice teachers are encouraged to use platforms, work with multimedia, use available computer hardware, have online discussion, be able to use Microsoft Office to complete written tasks on time, and be able to use some database programs to create tables as well as store and retrieve data in order to be able to use electronic presentation software. Furthermore, preservice teachers have to be able to navigate the internet, search effectively for data, use email to send attachments, download documents or software from the web, and know major websites for teaching Chinese as a foreign language in addition to the most common applications used by international students during the learning process and social media preferred during their daily communication.

Generally, we divided pedagogy skills into classroom management and content-related competencies to make preservice teachers able to reflect on teaching practices and identify in their practice what works and what does not work in classroom management via the ability to create a learning environment that challenges open, engaging, and rich communication that enables international students to meet their targeted learning outcomes as well as 
being interacted with and motivated, knowing students not only academically but also in terms of their interests, personalities, and learning styles.

Preservice teachers have to adopt the knowledge of representations of subject matter, understanding students' conceptions of the subject in addition to the learning and teaching implications that were associated with the specific subject matter; inclusive teaching refers to any number of teaching approaches that address the needs of students with a variety of backgrounds, learning styles, and abilities, and has to use universal design principles to create accessible classes for those with various learning preferences.

To develop didactic competency we encouraged preservice teachers and instructed them in varied approaches to designing lectures, lessons, or workshops, and encouraged the use of different opportunities offered by smart teaching tools to offer more options during lessons, adding a variety of instruction which will, in turn, allow preservice teachers to be more effectively harness their talents and also been in a better position to guide all international students.

We encouraged preservice teachers to organize large and small group activities, display good social skills with a welcoming and positive attitude to set the tone of behavior, assign classroom jobs to provide opportunities to demonstrate responsibilities, teamwork, and leadership, and roleplay social situations with international students that can allow social skills in direct or inadvertent ways. We support creating a meeting class to support preservice teachers to be diplomatic, understand leadership, solve problems, and take responsibility with explicit instruction.

\subsection{Design}

We developed an experimental training program to improve the four main competencies of preservice TCFL teachers (TC, PC, DC, and SC). A total of 12 chapters were developed based on this module to promote different skills with activities before, during, and after class. We used different resources related to international students with the learning of standard HSK text course, the new concept of Chinese interpretation of teaching materials, reference of the teaching plan, HSK standard tutorial, lesson plan, and analysis of grammatical errors in foreigners learning Chinese.

Other books and online materials used to instruct preservice teachers were the use of an introduction to teaching Chinese as a foreign language, an explanation of 201 cases of grammar in TCFL, teaching design questions, teaching materials in China, overseas teaching materials, typical sentences of international students, language skill levels, and classifications.

Pretest and posttest design methods will be conducted during the experiment's start and end to compare participant groups and measure the degree of the change that occurred as a result of the treatments or interventions. Preservice TCFL teachers took part in the pretest before starting the experiment to measure those aspects stated in the learning objectives; the post-test is conducted after completion of the 18 weeks of the experiment.

\subsection{Implementation}

In the study the teacher deviated from the traditional method of lecturing. We encouraged anytime, everywhere learning and evaluated interactive mobile learning by utilizing the capabilities of this smart teaching framework (MT). Before each session the instructor posted a pre-class learning test on the platform, which required students to read a chapter, view a documentary or lecture, or complete a case study. The learning tool that was posted was based on research. The teacher did not repeat the actual knowledge posted online during face-to-face courses. Instead of doing activities as a whole class or dividing students into teams, we did them individually. Quick answer games, group discussions, and impromptu roleplaying on stage were among the events, which included a five- to seven-minute class presentation for each preservice teacher with a recorded video of teachers to analyze and point out the development of preservice teachers as well as brainstorm.

Figure 4 depicts a typical teaching technique and the diversity of class activities we conducted before, during, and after class during the research. Some class events are not set 
in stone and can be adjusted at any time to meet the teacher's needs. This graphic guided the teaching process and displayed a teacher's innovative efforts to make learning more pleasurable and interactive for his students. Some preservice teachers' presentations had some difficulties or interrupted teachers' ability to be flexible during real-world classrooms and be prepared for any unplanned event that may arise throughout teaching Chinese to international students.

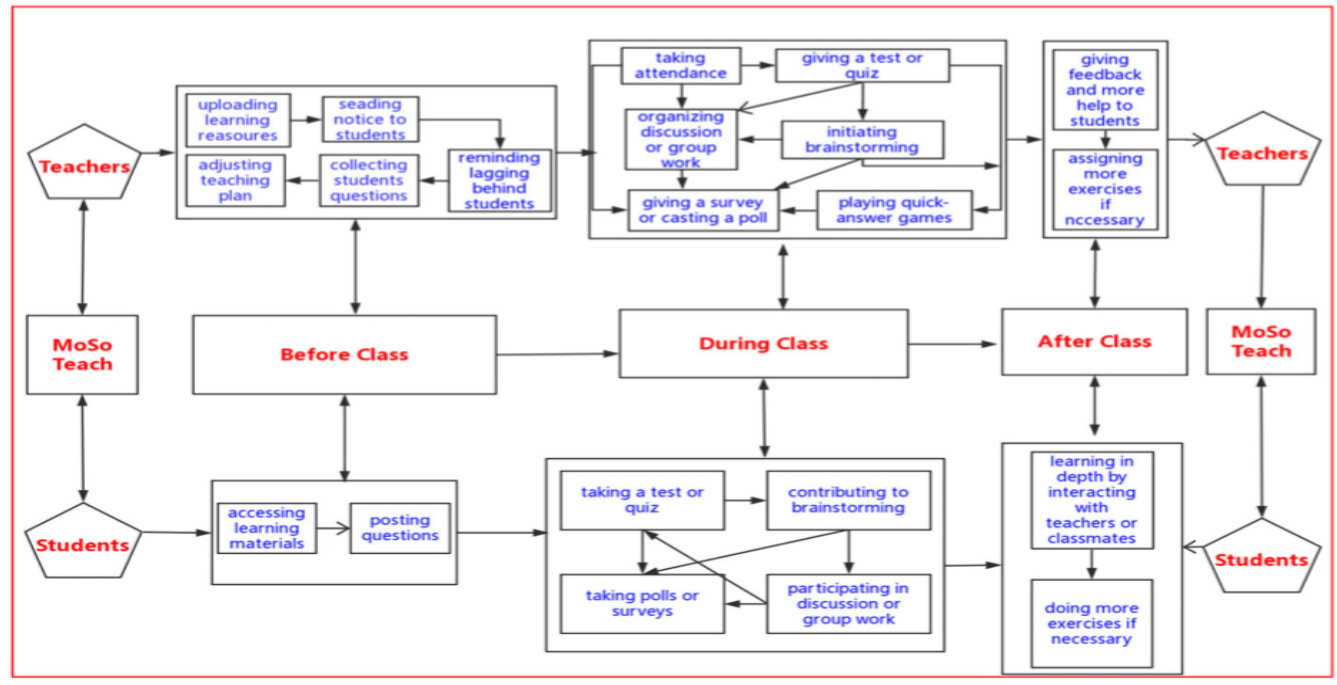

Figure 4. Design of teaching-learning model.

\section{Results}

During the experiment, except for the instructor-teacher-given lectures, presentations, transmission of content, and preclass as well as postclass activities with tasks and homework, preservice teachers are also required to play the role of a teacher in every lesson for 18 weeks to display what they are learning, and all preservice teachers are required to perform a presentation between five and seven minutes in length with respect to what they learned with the use of the various technologies adequate to their teaching tasks. The preparation of the course should also be oriented by the instructor teacher to pay attention to preclass, what activities will be presented, how much time each sequence will take, and how to manage the classroom.

All activities were recorded to be analyzed and given to preservice teachers using MT and RC, providing them with more opportunities to learn from their own teaching practice, not only after a presentation. All other preservice teachers have to give their feedback and score from 0 to 100 to the presenter through the online teaching system, which will be added to the instructor score and foreign teacher score in order to evaluate the presentation, in addition to feedback from the foreign teacher and instructor regarding the use of the variety of activities and how to display active teaching and promote students in the classroom, and also if preservice teachers respect what they learned before and the ability to use teaching materials and their body to express themselves in addition to if there is anything that should be changed or improved. Figure 5 describes some of the activities from the smart teaching tools with preservice teachers achievement and personal comprehensive evaluation and score of assignment and more other details in the figure.

\subsection{Preliminary Analysis}

The Pearson correlation analyses showed that the four main variables (i.e., technological competency, pedagogical competency, didactical competency, and social competency) were positively associated. Moreover, a preservice teacher's gender was positively associated with all other variables. Furthermore, a preservice teacher's age was positively 


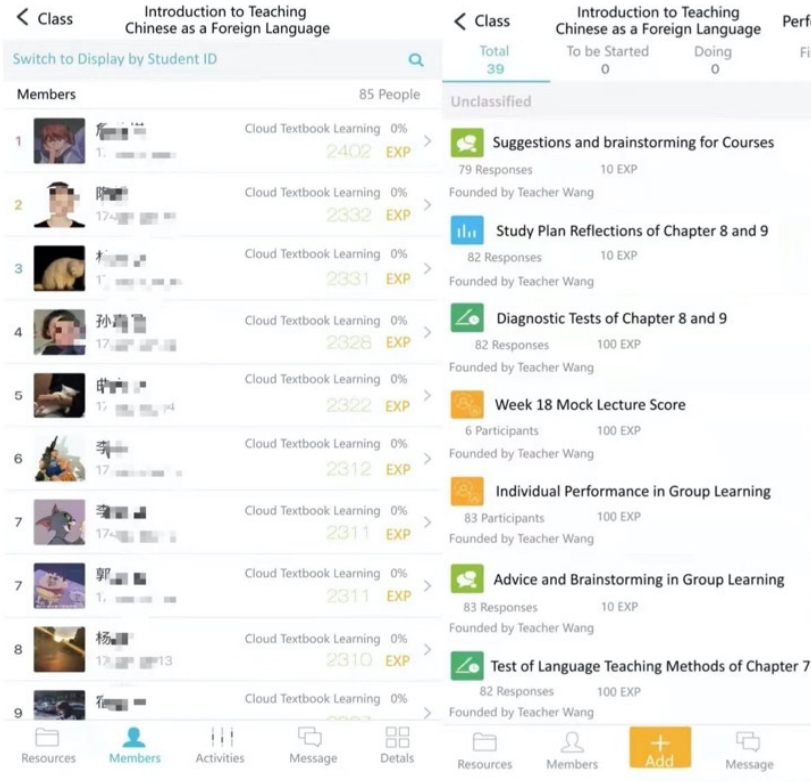

associated with PC, DC, and SC, but negatively associated with TC. More details about the results of Pearson correlation analyses can be shown in Table 2.

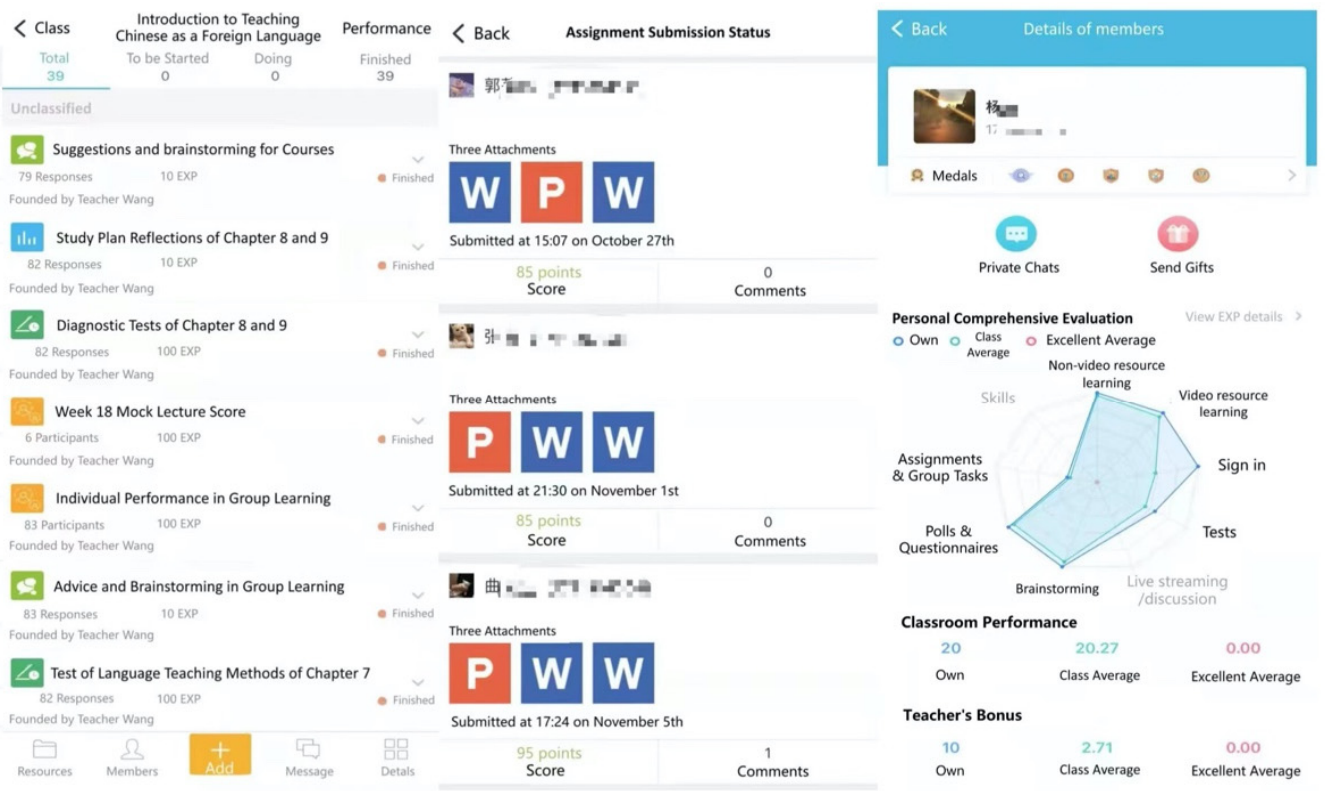

Figure 5. Preservice teacher learning activities and environment.

Table 2. Descriptive statistics and intercorrelation between the main variables $(n=82)$.

\begin{tabular}{lccccccc}
\hline & $\mathbf{M}$ & SE & $\mathbf{1}$ & $\mathbf{2}$ & $\mathbf{3}$ & $\mathbf{4}$ & $\mathbf{5}$ \\
\hline 1. Age & 19.76 & $0.08^{*}$ & 1 & - & - & - & - \\
\hline 2. Gender & 1.88 & $0.03^{*}$ & $-0.06^{* *}$ & 1 & - & - & - \\
\hline 3. TC & 3.02 & $0.04^{* *}$ & $-0.08^{* *}$ & $0.10^{* *}$ & 1 & - & - \\
\hline 4. PC & 3.14 & $0.04^{* *}$ & $0.09^{* *}$ & $0.03^{* *}$ & $0.37^{* *}$ & 1 & - \\
\hline 5. DC & 3.30 & $0.04^{* *}$ & $0.06^{* *}$ & $0.09^{* *}$ & $0.27^{* *}$ & $0.35^{* *}$ & - \\
\hline 6. SC & 3.28 & $0.04^{* *}$ & $0.05^{* *}$ & $0.12^{* *}$ & $0.26^{* *}$ & $0.18^{* *}$ & $0.39^{* *}$ \\
\hline
\end{tabular}

Note: TC, Technological competency; PC, Pedagogical competency; DC, Didactical competency; SC, Social competency; ${ }^{*} p<0.05 ;{ }^{* *} p<0.01$.

\subsection{Experimental Analysis}

Taking the academic results of the EG and CG to compare the mean and check the independent samples test of preservice TCFL teachers, testing both groups allow us to know that there is no significant difference in the starting point of learners between the EG and CG; the detailed results are shown in Table 3.

Table 3. Difference of pretest scores between the EG and CG.

\begin{tabular}{cccc}
\hline Participants & F & T & Sig (Two-Tailed) \\
\hline EG and CG & 46.18 & $-0.95^{*}$ & 0.178 \\
\hline
\end{tabular}

Note: EG, Experimental group; CG, Control group; ${ }^{*} p<0.05$.

\subsection{Experimental Design Pretest and Post-Test}

For many true experimental designs pretest and post-test designs are the preferred methods to compare participant groups and measure the degree of change occurring due to treatments or interventions. Preservice TCFL teachers took part in the pretest before starting the experiment to measure those aspects stated in the learning objectives, and the 
post-test is conducted after the completion of the 18 weeks of the experiment. More details are in Table 4.

Table 4. Preservice TCFL teachers' paired samples statistics.

\begin{tabular}{rccccc}
\hline & & M & N & S.D & S.E \\
\hline \multirow{2}{*}{ TC } & TC_Pretest & $1.78^{* *}$ & 82 & $0.24^{* * *}$ & $0.02^{* * *}$ \\
\cline { 2 - 6 } & TC_Posttest & $3.02^{* *}$ & 82 & $0.36^{* * *}$ & $0.04^{* * *}$ \\
\hline \multirow{2}{*}{ PC } & PC_Pretest & $1.85^{* *}$ & 82 & $0.27^{* * *}$ & $0.03^{* * *}$ \\
\cline { 2 - 6 } & PC_Posttest & $3.14^{* *}$ & 82 & $0.39^{* * *}$ & $0.04^{* * *}$ \\
\hline \multirow{2}{*}{ DC } & DC_Pretest & $1.86^{* *}$ & 82 & $0.28^{* * *}$ & $0.03^{* * *}$ \\
\cline { 2 - 6 } & DC_Posttest & $3.30^{* *}$ & 82 & $0.39^{* * *}$ & $0.04^{* * *}$ \\
\hline \multirow{2}{*}{ SC } & SC_Pretest & $1.75^{* *}$ & 82 & $0.23^{* * *}$ & $0.02^{* * *}$ \\
\cline { 2 - 6 } & SC_Posttest & $3.28^{* *}$ & 82 & $0.37^{* * * *}$ & $0.04^{* * *}$ \\
\hline \multirow{2}{*}{ Not: } & & &
\end{tabular}

Note: ${ }^{* *} p<0.05 ;{ }^{* * *} p<0.01$.

The paired samples table results confirm that all competencies, TC, PC, DC, and SC, have been improved between the pretest and post-test, as the technological competency TC_Pretest score $\left(\mathrm{N}=82, \mathrm{M}=1.78^{* *}\right)$ and TC_Posttest score $\left(\mathrm{N}=82, \mathrm{M}=3.02{ }^{* *}\right)$ have been increased during the experiment. The same is true for the pedagogical and didactical competencies PC_Pretest $\left(\mathrm{N}=82, \mathrm{M}=1.85^{* *}\right)$ and PC_Posttest $\left(\mathrm{N}=82, \mathrm{M}=3.14^{* *}\right)$ scores as well as the didactic competencies DC_Pretest $\left(\mathrm{N}=82, \mathrm{M}=1.86^{* *}\right)$ and DC_Posttest $\left(\mathrm{N}=82, \mathrm{M}=3.30^{* *}\right)$ scores; the social competency scores displayed the highest improvement compared to the other competencies: SC_Pretest $\left(\mathrm{N}=82, \mathrm{M}=1.75^{* *}\right)$ and SC_Posttest $\left(\mathrm{N}=82, \mathrm{M}=3.28^{* *}\right)$.

\subsection{Paired Samples t-Test}

The paired samples $t$-test is used to compare two means that are from the same individual, object, or related units, and the purpose of the test is to determine whether there is statistical evidence that the mean difference between paired observations on a particular outcome is significantly different from zero. Table 5 shows the results of the paired samples $t$-test.

Table 5. Results of the paired samples $t$-test.

\begin{tabular}{|c|c|c|c|c|c|c|c|c|c|}
\hline & & \multicolumn{5}{|c|}{ Paired Differences } & \multirow[t]{3}{*}{$\mathrm{T}$} & \multirow[t]{3}{*}{ df } & \multirow[t]{3}{*}{ Sig. } \\
\hline & & \multirow{2}{*}{$\mathbf{M}$} & \multirow{2}{*}{ S.D } & \multirow{2}{*}{ S.E } & \multicolumn{2}{|c|}{ 95\% C.I.D } & & & \\
\hline & & & & & Lower & Upper & & & \\
\hline $\mathrm{TC}$ & $\begin{array}{l}\text { TC_Pretest- } \\
\text { TC_Posttest }\end{array}$ & $1.24^{* *}$ & $0.43^{* *}$ & $0.04 * *$ & $1.14^{* *}$ & $1.34^{* *}$ & 25.66 & 81 & 0.000 \\
\hline PC & $\begin{array}{l}\text { PC_Pretest- } \\
\text { PC_Posttest }\end{array}$ & $1.28 * *$ & $0.48^{* *}$ & $0.05^{* *}$ & $1.17^{* *}$ & $1.38^{* *}$ & 23.91 & 81 & 0.000 \\
\hline DC & $\begin{array}{l}\text { DC_Pretest- } \\
\text { DC_Posttest }\end{array}$ & $1.44^{* *}$ & $0.43^{* *}$ & $0.04 * *$ & $1.34^{* *}$ & $1.53 * *$ & 30.38 & 81 & 0.000 \\
\hline SC & $\begin{array}{l}\text { SC_Pretest- } \\
\text { SC_Posttest }\end{array}$ & $1.53^{* *}$ & $0.43^{* *}$ & $0.04^{* *}$ & $1.43^{* *}$ & $1.62 * *$ & 31.91 & 81 & 0.000 \\
\hline
\end{tabular}

The results show a significant average difference between the technological competency pretest and the technological competency post-test $(t 81=25.667, p<0.001)$. On average, the technological competency post-test scores were 1.24 points higher than the technological competency pretest scores (95\% CI [1.14, 1.34]). 
There was a significant average difference between the pedagogical competency pretest and pedagogical competency post-test $(\mathrm{t} 81=23.912, p<0.001)$. On average, the pedagogical competency post-test scores were 1.28 points higher than those of the pedagogical competency pretest $(95 \%$ CI $[1.17,1.38])$.

For didactical competency, there was a significant average difference between the didactical competency pretest and the didactical competency post-test $(\mathrm{t} 81=30.382$, $p<0.001)$. On average, the didactical competency post-test scores were 1.44 points higher than those of the didactical competency pretest (95\% CI [1.34, 1.53]).

Related to social competency, there was a significant average difference between the social competency pretest and the social competency post-test $(\mathrm{t} 81=31.916, p<0.001)$. On average, social competency post-test scores were 1.530 points higher than those of the social competency pretest (95\% CI [1.43, 1.62]).

From Table 4 we can conclude that preservice TCFL teachers have effectively developed their competency during the experiment; the paired sample is $0.000<0.05$, showing that there is a significant difference, and the post-test score is significantly higher than the pretest score for TC, PC, DC, and SC.

\subsection{Academic Performance of the EG and CG}

An independent samples $t$-test was conducted on the academic performance of two groups, the experiment group ( $E G, N=82)$ and the control group $(C G, N=64)$; from the results, the mean of the experimental group ( $E G, M=81.16^{* *}$ ) and the control group (CG, $\mathrm{M}=77.01^{* *}$ ) are detailed in Table 6.

Table 6. EG and CG statistics.

\begin{tabular}{cccccc}
\hline & Group & N & M & S.D & S.E \\
\hline \multirow{2}{*}{ Score } & EG & 82 & $81.18^{* *}$ & $3.57^{* *}$ & $0.39^{* *}$ \\
\cline { 2 - 6 } & CG & 64 & $77.01^{* *}$ & $15.64^{* *}$ & $1.95^{* *}$ \\
\hline Note: ${ }^{* *} p<0.05$. & & & & &
\end{tabular}

The independent samples $t$-test compares the means of our two independent groups experiment group with the control group to determine whether there is statistical evidence that the associated preservice TCFL teachers' means are significantly different or equal to 0 (Table 7).

Table 7. Independent samples test.

\begin{tabular}{|c|c|c|c|c|c|c|c|c|c|c|}
\hline & & \multicolumn{4}{|c|}{ Levene's Test for Equality of Variances } & \multicolumn{5}{|c|}{$t$-Test for Equality of Means } \\
\hline & & \multirow{2}{*}{$F$} & \multirow{2}{*}{ Sig. } & \multirow{2}{*}{$\mathbf{t}$} & \multirow{2}{*}{ df } & \multirow{2}{*}{ Sig. } & \multirow{2}{*}{$\mathbf{M}$} & \multirow{2}{*}{ S.E } & \multicolumn{2}{|c|}{ 95\% C.I.D } \\
\hline & & & & & & & & & Lower & Upper \\
\hline \multirow{2}{*}{ Score } & Equal variances assumed & 52.317 & 0.000 & 2.339 & 144 & 0.021 & $\underset{* *}{4.17}$ & 1.78 & $\underset{* *}{0.64}$ & $\begin{array}{c}7.69 \\
* *\end{array}$ \\
\hline & Equal variances not assumed & & & 2.091 & 68.16 & 0.040 & $\underset{* *}{4.17}$ & $\underset{* *}{1.99}$ & $\underset{* *}{0.18}$ & ${ }_{* *}^{8.15}$ \\
\hline
\end{tabular}

Note: ${ }^{* *} p<0.05$.

\subsection{Effect of Teaching Activities}

To further analyze the differences in participants in teaching activities using Moso Teach and Rain Classroom, this study divided learners into a high group (HG), medium group (MG), and low group (LG) based on learning effects. Different learning activities have different effects on learners, and there are differences in the quality of learners' behavior. Analyzing and discovering the differences in the participation of learning activities can effectively help researchers improve teaching activities and perfect teaching modes from the perspective of activity analysis and design, starting from the three nodes of the teaching model. The results can be found in Table 8 . 
Table 8. Effect of teaching activities.

\begin{tabular}{|c|c|c|c|c|}
\hline Activities & Group Comparison & F & $\mathbf{t}$ & Sig (Two-Tailed) \\
\hline \multirow{3}{*}{$\begin{array}{l}\text { Resource } \\
\text { learning }\end{array}$} & LG and HG & 2.441 & -0.956 & 0.345 \\
\hline & LG and MG & 5.180 & -1.571 & 0.122 \\
\hline & $\mathrm{HG}$ and $\mathrm{MG}$ & 0.208 & -0.537 & 0.593 \\
\hline \multirow{3}{*}{$\begin{array}{l}\text { Activity } \\
\text { learning process }\end{array}$} & LG and HG & 0.940 & -11.117 & 0.000 \\
\hline & LG and MG & 0.428 & -9.615 & 0.000 \\
\hline & $\mathrm{HG}$ and $\mathrm{MG}$ & 0.298 & 3.756 & 0.000 \\
\hline \multirow{3}{*}{$\begin{array}{l}\text { Activity } \\
\text { interaction }\end{array}$} & LG and HG & 1.968 & -2.240 & 0.030 \\
\hline & LG and MG & 9.890 & -3.340 & 0.002 \\
\hline & $\mathrm{HG}$ and $\mathrm{MG}$ & 4.081 & -0.946 & 0.338 \\
\hline \multirow{3}{*}{$\begin{array}{l}\text { Activity } \\
\text { evaluation }\end{array}$} & LG and HG & 0.644 & -6.760 & 0.000 \\
\hline & LG and MG & 3.609 & -4.030 & 0.000 \\
\hline & HG and MG & 1.193 & 6.010 & 0.000 \\
\hline \multirow{3}{*}{$\begin{array}{l}\text { Record } \\
\text { class participation }\end{array}$} & LG and HG & 0.454 & -0.815 & 0.420 \\
\hline & LG and MG & 0.003 & 0.291 & 0.772 \\
\hline & HG and MG & 0.541 & 1.167 & 0.248 \\
\hline
\end{tabular}

The results of the resource analysis show that in terms of whether the learners meet the prescribed learning standards, mainly whether they complete the resource learning, most of the learners can meet the standards and that there is no difference among the three groups. From the analysis results, the part of resources cannot reflect the learning quality of learners.

By analyzing learning activities data in the smart learning platform it is found that learners show differences in the learning process, interaction, and evaluation. The data of classroom tasks, classroom questions, and answers are collected in the learning process. From the frequency and quality of learning events, the results show differences among the three groups. The LG was significantly weaker than the middle and high groups. It is worth noting that the performance of the MG is better than that of the HG. The reason for this is that the frequency of learning events in the MG is lower than that of the HG, but the quality of learning events in the MG is better than that in the HG. Therefore, the comprehensive results show that the learning quality of the MG is better than that of the other two groups in this dimension. The interaction dimension mainly includes brainstorming, voting, and group discussion data. The results showed that the HG and the MG were better than the LG, but there was no significant difference between the HG and the MG. The activities of the evaluation dimension mainly include question and answer, discussion, star evaluation, and scores. The results showed that the HG was better than the MG, and that the MG was better than the LG.

This study is based on a smart learning platform to record learners' classroom performance regarding activity participation, resource uploading, and resource browsing. The results showed no significant difference between the three groups of learners.

\section{Discussion}

The first research question of this study to answer was how to improve preservice TCFL teacher competencies by integrating smart teaching tools into their learning process. As a result of all the conducted activities we could understand how important the field of teaching a foreign language is in the field of education and how it can play an important role not only for the Chinese language but for other languages. Developing the teaching of Chinese as a foreign language requires a substantial effort from researchers. 
Teaching preservice teachers plays an important role not only for an instructor or a college/university but also for a country and humanity; it shows the development of the educational system of a country, and from the experiment we can notice and leaders in charge of teachers' instruction can take in particular educational measures that focus on organizational and curricular diversity, allowing preservice teachers to exercise their autonomy and have a flexible teaching organization, providing customized attention to preservice TCFL teachers based on their needs.

The integration of smart teaching tools and a well-designed teaching-learning process plays an important role in all fields, not only in the teaching of the Chinese language. The integration of smart teaching tools in the teaching process helped preservice teachers to integrate technology into their teaching practice; the importance of the use of Moso Teach and Rain Classroom could help to make preservice teachers familiar with ICT and have access to critical databases to collect required information, be familiar with blogs, have a clear understanding of hardware and software with the use of instructional packages, and be familiarized with computer terminology. In the framework of second language acquisition as cross curricular material we cannot ignore the use of information and communications technology (ICT) in the learning process. As a result, while the approach, which arouses a deep interest in the didactic areas of second language acquisition, is communicative, it should be noted that these types of assignments will be adjusted to different aspects that influence our educational practice. As a result, this accomplishes the following goals:

Integrate smart teaching tools into the learning process as a critical competency that aids in the acquisition of the target foreign language; in the classroom, use ICT to work on information processing, authentic communication, and learner autonomy as the creator of their learning process; assist preservice teachers in organizing, evaluating, and deciding on the information that is presented; provide preservice teachers with a wide range of supports, formats, and activities to transition from receivers to makers to improve their pedagogical and didactical skills; and authentic and real-time documents are used to expose preservice instructors to cultural themes in a social environment.

In terms of the second question of this paper, how to integrate technological, pedagogical, didactic, and social competencies intro preservice teachers' daily teaching CFL, by designing a teaching model with preclass, during the class, and postclass activities as well as a teaching-learning process, preservice teachers experience the advantages of the use of smart teaching tools. Facilities will allow preservice teachers to adopt the first use of new technology and consider the importance of the combination of different and adequate pedagogy, didactic in the teaching process with respect of the differentiation of international students' background, origin, religion, and culture.

They allow preservice teachers to design effective learning experiences, create a rich learning environment, and prepare schemes of work and lessons to access student performance.

\section{Conclusions}

To cultivate preservice teachers, they must be imparted with relevant theoretical knowledge and cultivate their ability to express themselves and spread knowledge. Based on the full study of related smart teaching tools, this research is based on Moso Teach and Rain Classroom combined with the content characteristics of TCFL; the teaching and learning activity model is designed from five processes of analysis, design, development, implementation, and evaluation. The model is aimed at both teachers and students (preservice teachers) to design teaching activities from three stages: before, in, and after class.

From the perspective of preservice teachers, Moso Teach and Rain Classroom can collect all types of state and students' data in time and form a smart learning environment that supports students' learning in all directions. Before class, Moso Teach uses mobiles to provide learning resources to learners and help preservice teachers to collect learning problems. Moso Teach and Rain Classroom build a bridge between teachers and students and help students complete personal learning, cooperative learning, communication and 
discussion, achievement display, and other teaching tasks in the class. Meanwhile, it also collects students' data in real-time during the learning process, which lays the foundation for process evaluation. After class, the smart teaching platform displays the visual results of learning analytics and feeds the teacher's evaluation back to the students. Additionally, through the discussion area and other functions, teachers and students can communicate after class.

\subsection{Research Contribution}

In this study, Moso Teach and Rain Classroom are used to create an experimental environment to study the ability training of preservice TCFL teachers. This study adopts a quasi-experimental research method and designs a control experiment in the empirical study. The experimental group used the teaching activity and classroom teaching models proposed in this study. The control group was taught traditionally. The results show that the teaching activity and classroom teaching model based on Moso Teach and Rain Classroom significantly impact preservice teachers' technical ability, teaching ability, expression ability, and social ability.

In addition, to better measure the impact of this research on the teaching effect of Chinese as a foreign language, the author also analyzed the teaching practice effect of preservice teachers from the perspective of international students. The results encourage the proposed model and experiment strategy, and this research has achieved the research goal of improving the teaching skills of TCFL teachers. The specific conclusions are as follows:

(1) Intelligent analysis and service based on learning analysis prove the advantages of mobile education technology in teaching innovation;

(2) The design of teaching activities based on a smart teaching platform improves learning performance and classroom participation;

(3) The smart teaching system model proposed in this study significantly improves the technological competencies, pedagogical competencies, didactic competencies, and social competencies of preservice TCFL teachers;

(4) The use of smart teaching tools in preservice TCFL teaching can improve future teachers' teaching skills and improve classroom efficiency.

Generally, the smart teaching system and model strategy can improve these abilities, build an active classroom, and encourage preservice teachers to use smart teaching tools in their teaching-learning process. Using the new teaching system based on smart teaching tools is of great value and significance to improve TCFL teachers' teaching expression and social competencies.

\subsection{Limitation and Future Work}

The experiment results show how actively preservice teacher pedagogical, technological, didactical, and social competency have been improved after eighteen weeks from pretest to post-test. From the academic results of preservice teachers after the final exam and results from Moso Teach and Rain Classroom, we can indicate that a smart learning platform combined with very-well-created activities could provide an augmentation of preservice teachers' engagement in progress in a wide range of activities and contexts indeed, from self-learning to team collaboration, class attendance, and synchronous postings on a discussion forum, among others. Institutions have big classes with minimal opportunities for contact; therefore, these findings are crucial, especially to develop preservice teachers' technological, pedagogical, didactical, and social competencies.

Although this exploratory paper has contributed significantly to applying smart teaching technologies in formal education, the research still has certain limitations. Observations revealed that some preservice TCFL teachers were distracted from their learning tasks while participating in classroom activities. Furthermore, MT only gathers information about who reads or watches a particular piece of content and does not provide data on how long 
students spend on it. Third, the findings generated by MT and RC are not comprehensive enough to judge preservice teachers' performance and differ from the outcomes.

Therefore, we need to conduct further research on the following aspects in the future. First, the 'intelligence' of the smart platform requires further development. We need to design a task retention reminder system to reduce preservice TCFL teachers' attention. Second, to improve its effectiveness in promoting teaching we need to design more useful learner classification features and learning strategies based on Moso Teach and Rain Classroom. Third, we need to refine the recorded information of the preservice learning process, such as the time data of viewing materials, the behavior data of preservice teachers jumping, etc., to help teachers improve the design of curriculum materials. Finally, we need to reduce the delay phenomenon when teachers and preservice teachers use the learning platform to communicate, fully integrate the intelligent learning platform with students learning processes to systematically and comprehensively evaluate preservice teachers, and finally conduct an application of the experiment with international students to confirm the development of preservice TCFL teachers' competencies.

Author Contributions: Conceptualization, M.O., W.Z., Q.J. and L.Q.; Data Curation, M.O., Y.W. and Y.Z.; Formal Analysis, Q.J., Y.L. and X.X.; Investigation, M.O.; Methodology, M.O.; Project Administration, W.Z., Y.W. and Q.J.; Resources, W.Z., Y.W. and Y.Z.; Software, M.O., Y.W., Y.Z. and Y.L.; Supervision, W.Z., Y.W. and Y.Z.; Validation, W.Z., Y.W. and Y.Z.; Visualization, W.Z.; WritingOriginal Draft, M.O.; Writing—Review and Editing, M.O., W.Z., Q.J., X.X. and L.Q. All authors have read and agreed to the published version of the manuscript.

Funding: National Natural Science Foundation of China "Research on Learning Model and Intervention Mechanism in E-learning Space" (Project Number [62077012]).

Institutional Review Board Statement: The study was conducted in accordance with the Declaration of Helsinki, and approved by the Ethics Committee of the local university's School of Information Science and Technology (Protocol code: 20190073 approved in 15 September 2019).

Informed Consent Statement: Informed consent was obtained from all subjects involved in the study and written informed consent has been obtained from the subject to publish this paper.

Data Availability Statement: Not applicable.

Conflicts of Interest: The authors declare no conflict of interest.

\section{References}

1. Gong, Y.F.; Gao, X.A.; Lyu, B. Teaching Chinese as a second or foreign language to non-Chinese learners in mainland China (2014-2018). Lang. Teach. 2020, 53, 44-62. [CrossRef]

2. Gong, Y.; Lai, C.; Gao, X. The teaching and learning of Chinese as a second or foreign language: The current situation and future directions. Front. Educ. China 2020, 15, 1-13. [CrossRef]

3. Moloney, R.; Xu, H. Transitioning beliefs in teachers of Chinese as a foreign language: An Australian case study. Cogent Educ. 2015, 2, 1024960. [CrossRef]

4. Xinhuanet. 2019. Available online: http://www.xinhuanet.com/politics/2019-06/03/c_1124578973.htm (accessed on 6 February 2022).

5. Yang, G.; Quanjiang, G.; Michael, L.; Chun, L.; Chuang, W. Developing literacy or focusing on interaction: New Zealand students' strategic efforts related to Chinese language learning during study abroad in China. System 2021, 98, 102462. [CrossRef]

6. Block, D. The rise of identity in SLA research, post Firth and Wagner (1997). Mod. Lang. J. 2007, 91, 863-876. [CrossRef]

7. Diao, W. Between the standard and non-standard: Accent and identity among transnational Mandarin speakers studying abroad in China. System 2017, 71, 87-101. [CrossRef]

8. Kinginger, C. Identity and language learning in study abroad. Foreign Lang. Ann. 2013, 46, 339-358. [CrossRef]

9. Cervatiuc, A. Identity, good language learning, and adult immigrants in Canada. J. Lang. Identity Educ. 2009, 8, $254-271$. [CrossRef]

10. Gao, X.; Cheng, H.; Kelly, P. Supplementing an uncertain investment? Chinese alliances for English language learning. J. Asia Pac. Commun. 2008, 18, 9-29. [CrossRef]

11. Hajar, A. Identity, investment and language learning strategies of two Syrian students in Syria and Britain. Lang. Cult. Curric. 2017, 30, 250-264. [CrossRef]

12. Kinginger, C. Language learning in study abroad: Case studies of Americans in France. Mod. Lang. J. 2008, 92, 1-124. [CrossRef]

13. Norton, B. Identity and Language Learning; Multilingual Matters: Bristol, UK, 2013. 
14. Lai, C.; Li, Z.; Gong, Y. Teacher agency and professional learning in cross-cultural teaching contexts: Accounts of Chinese teachers from international schools in Hong Kong. Teach. Teach. Educ. 2016, 54, 12-21. [CrossRef]

15. Ma, X.; Gong, Y.; Gao, X.; Xiang, Y. The teaching of Chinese as a second or foreign language: A systematic review of the literature 2005-2015. J. Multiling. Multicult. Dev. 2017, 38, 815-830. [CrossRef]

16. Tian, M.; Lowe, J. Intercultural identity and intercultural experiences of American students in China. J. Stud. Int. Educ. 2014, 18, 281-297. [CrossRef]

17. Oubibi, M.; Zhao, W. Pre-service Teachers Teaching Chinese as Foreign language integration of Technological Pedagogical Didactical Social ICT Competencies. In Proceedings of the 2019 Eighth International Conference on Educational Innovation through Technology (EITT), Biloxi, MS, USA, 27-31 October 2019; pp. 131-136.

18. $\mathrm{Li}, \mathrm{Y}$. Research on the construction of TCFL resource database system based on artificial intelligence. J. Intell. Fuzzy Syst. 2021, 1-12. [CrossRef]

19. Hu, Z.; Guo, H. Topics and their Evolution in the research field of Teaching Chinese as A Foreign Language: A bibliometrics analysis based on VOSviewer. In Proceedings of the 2021 2nd International Conference on Artificial Intelligence and Education (ICAIE), Dali, China, 18-20 June 2021; pp. 646-649.

20. Wang, J.; Gao, F.; Li, J.; Zhang, J.; Li, S.; Xu, G.T.; Xu, L.; Chen, J.; Lu, L. The usability of WeChat as a mobile and interactive medium in student-centered medical teaching. Biochem. Mol. Biol. Educ. 2017, 45, 421-425. [CrossRef]

21. Tu, S.; Yan, X.; Jie, K.; Ying, M.; Huang, C. WeChat: An applicable and flexible social app software for mobile teaching. Biochem. Mol. Biol. Educ. 2018, 46, 555-560. [CrossRef]

22. Tang, W.; Zhang, H.; Tan, X.; Yin, J.; Ding, Y.; Cao, G. Research on reform of epidemiology teaching. Zhonghua Liuxingbingxue Zazhi 2018, 39, 1009-1012.

23. Chen, Y. Application of Modern Technology in Teaching Chinese as a Foreign Language. In Proceedings of the Training, Testing and Evaluation. 2021, pp. 217-220. Available online: https:/ / elibrary.ru/item.asp?id=46279307 (accessed on 6 February 2022).

24. Qifeng, Z. An Investigation into Chinese Spoken Language Proficiency for Preparatory Students in China. Chin. Teach. World 2016, 3, 368-378.

25. Jing, S. Teaching Chinese personal anaphora to second language learners. Chin. Teach. World 2013, 4, 537-547.

26. Curdt-Christiansen, X.L. Reading the world through words: Cultural themes in heritage Chinese language textbooks. Lang. Educ. 2008, 22, 95-113. [CrossRef]

27. Loh, E.K.; Tam, L.C.; Lau, K.-C. Moving between language frontiers: The challenges of the medium of instruction policy for Chinese as a second language. Lang. Policy 2019, 18, 131-153. [CrossRef]

28. Ke, C. A model of formative task-based language assessment for Chinese as a foreign language. Lang. Assess. Q. 2006, 3, 207-227. [CrossRef]

29. Hu, X.; Gong, Y.; Lai, C.; Leung, F.K. The relationship between ICT and student literacy in mathematics, reading, and science across 44 countries: A multilevel analysis. Comput. Educ. 2018, 125, 1-13. [CrossRef]

30. Pan, D.; Zhang, H.; Chen, W.; Lu, K. Transmission of multimedia contents in opportunistic networks with social selfish nodes. Multimedia Syst. 2015, 21, 277-288. [CrossRef]

31. Lai, C.; Gu, M.; Hu, J. Understanding legitimate teacher authority in a cross-cultural teaching context: Pre-service Chinese language teachers undertaking teaching practicum in international schools in Hong Kong. J. Educ. Teach. 2015, 41, 417-434 [CrossRef]

32. Wang, W.; Bale, J. Mentoring for new secondary Chinese language teachers in the United States. System 2019, 84, 53-63. [CrossRef]

33. Yang, J. Understanding Chinese language teachers' beliefs about themselves and their students in an English context. System 2019, 80, 73-82. [CrossRef]

34. Mohamed, O.; Han, J.; Wei, Z. Intelligent tutoring system: Besides the chances and challenges in artificial intelligence era and maker era. Int. J. Recent Sci. Res. 2018, 9, 29053-29062.

35. Gao, X.A.; Liao, Y.; Li, Y. Empirical studies on foreign language learning and teaching in China (2008-2011): A review of selected research. Lang. Teach. 2014, 47, 56-79. [CrossRef]

36. Zhao, X. Support Attracts Top Brains to China. China Daily. 2015. Available online: http://www.chinadaily.com.cn/2015-02/27 / content_19665339.htm (accessed on 6 February 2022).

37. Djalolov, F. The main difficulties in learning a new language. J. Foreign Lang. Linguist. 2021, 2. Available online: https: / / ruslit.jspi.uz/index.php/fll/article/view/2213 (accessed on 6 February 2022).

38. Liu, L.; Huang, X.; Wang, Y. Research on the Market Development of Teaching Chinese as a Foreign Language Based on Computer Aided. In Proceedings of the 2021 th International Conference on Information Systems and Computer Aided Education, Dalian, China, 24-26 September 2021; pp. 128-132.

39. Hsiao, C.H. Anxieties and Achievement Goals: Their Relationships in Contexts of Learning Chinese as a Foreign Language; University of Rochester: Rochester, NY, USA, 2014.

40. Luo, H.; Yang, C. Twenty years of telecollaborative practice: Implications for teaching Chinese as a foreign language. Comput. Assist. Lang. Learn. 2018, 31, 546-571. [CrossRef]

41. Ji, C.; Duffield, S.; Wageman, J.J.; Welch, A.G. Student perceptions of the classroom learning environment and motivation to learn Chinese. Chin. Second Lang. J. Chin. Lang. Teach. Assoc. USA 2017, 52, 111-126. [CrossRef] 
42. Mohamed, O.; Wei, Z. Motivation and satisfaction of international student studying Chinese language with technology of education. In Proceedings of the 2017 International Conference of Educational Innovation through Technology (EITT), Osaka, Japan, 7-9 December 2017; pp. 272-277.

43. Wei, P. Cross-Linguistic Perception and Learning of Mandarin Chinese Sounds by Japanese Adult Learners; University of Oregon: Eugene, OR, USA, 2016.

44. Su, J. Reassembly of plural and human features in the L2 acquisition of Chinese by adult Korean speakers. Second Lang. Res. 2019, 35, 529-555. [CrossRef]

45. Sun, M.; Mantero, M.; Summers, R. Chinese Adult Second Language Learners' Learning Strategy and Communicative Strategy Use. J. Second Mult. Lang. Acquis.-JSMULA 2014, 2, 22-35.

46. Ying, L.C.; Wah, F.P. App-MFoL mobile application development for learning mandarin as a foreign language. Int. J. Adv. Appl. Sci. 2016, 3, 47-51. [CrossRef]

47. Ding, H.; Zhang, Y.; Liu, H.; Huang, C.-R. A Preliminary Phonetic Investigation of Alphabetic Words in Mandarin Chinese. In Proceedings of the Interspeech, Stockholm, Sweden, 20-24 August 2017; pp. 3028-3032.

48. Lan, Y.; Lin, Y.; Kao, C.; Chang, K.; Sung, Y.; Liu, T. A Study of mobile-assisted oral communication in Mandarin Chinese as a second language. In Proceedings of the International Conference on Digital Learning Strategies and Applications (DLSA 2015), Sapporo, Japan, 8-11 May 2015.

49. Xu, Q.; Peng, H. Investigating mobile-assisted oral feedback in teaching Chinese as a second language. Comput. Assist. Lang. Learn. 2017, 30, 173-182. [CrossRef]

50. Zhang, H.; Roberts, L. The role of phonological awareness and phonetic radical awareness in acquiring Chinese literacy skills in learners of Chinese as a second language. System 2019, 81, 163-178. [CrossRef]

51. Guo, Y.; Li, X.; Fang, X.; Lin, X.; Song, Y.; Jiang, S.; Stanton, B. A comparison of four sampling methods among men having sex with men in China: Implications for HIV/STD surveillance and prevention. AIDS Care 2011, 23, 1400-1409. [CrossRef]

52. Yang, G.; Xiang, H.; Chun, L. CSL teachers' cognition in teaching intercultural communicative competence. System 2018, 78, 224-233.

53. Jeong, H.I.; Kim, Y. The acceptance of computer technology by teachers in early childhood education. Interact. Learn. Environ. 2017, 25, 496-512. [CrossRef]

54. Ho-kin, T.; John, L.C.-K.; Gwendoline, G.Y. Teaching 16 Chinese as a second language: Chinese perspective. In Quality in Teacher Education and Professional Development; Routledge: London, UK, 2021; p. 238.

55. Saavedra, A.R.; Opfer, V.D. Learning 21st-century skills requires 21st-century teaching. Phi Delta Kappan 2012, 94, 8-13. [CrossRef]

56. Drossel, K.; Eickelmann, B.; Vennemann, M. Schools overcoming the digital divide: In depth analyses towards organizational resilience in the computer and information literacy domain. Large-Scale Assess. Educ. 2020, 8, 9. [CrossRef]

57. Christensen, R.; Knezek, G. Self-report measures and findings for information technology attitudes and competencies. In International Handbook of Information Technology in Primary and Secondary Education; Springer: Berlin/Heidelberg, Germany, 2008; pp. 349-365.

58. Wilhelmsen, J.; Ørnes, H.; Kristiansen, T.; Breivik, J. Digitale utfordringer i høyere utdanning. Nor. IKT-Monit. $2009,1,2009$.

59. Becker, S.A.; Brown, M.; Dahlstrom, E.; Davis, A.; DePaul, K.; Diaz, V.; Pomerantz, J. NMC Horizon Report: 2018 Higher Education Edition; 2018; pp. 1-54. Available online: https:/ / eric.ed.gov/?id=ED594367 (accessed on 6 February 2022).

60. Mohamed, O.; Wei, Z. The Role of ICT in Learning Process of International Student at Chinese University. Int. J. Eng. Technol. 2018, 7, 97-100.

61. Aubusson, P.; Burke, P.; Schuck, S.; Kearney, M.; Frischknecht, B. Teachers choosing rich tasks: The moderating impact of technology on student learning, enjoyment, and preparation. Educ. Res. 2014, 43, 219-229. [CrossRef]

62. Clark, R.C.; Mayer, R.E. E-Learning and the Science of Instruction: Proven Guidelines for Consumers and Designers of Multimedia Learning; John Wiley \& Sons: Hoboken, NJ, USA, 2016.

63. Crompton, H.; Traxler, J. Mobile Learning and Higher Education: Challenges in Context; Routledge: London, UK, 2018.

64. Han, J.; Zhao, W.; Jiang, Q.; Oubibi, M.; Hu, X. Intelligent tutoring system trends 2006-2018: A literature review. In Proceedings of the 2019 Eighth International Conference on Educational Innovation through Technology (EITT), Biloxi, MS, USA, 27-31 October 2019; pp. 153-159.

65. Lai, C.; Zhu, W.; Gong, G. Understanding the quality of out-of-class English learning. TESOL Q. 2015, 49, 278-308. [CrossRef]

66. Hao, Y.; Lee, K.S. Inquiry of pre-service teachers' concern about integrating Web 2.0 into instruction. Eur. J. Teach. Educ. 2017, 40, 191-209. [CrossRef]

67. Teo, T.; Zhou, M. The influence of teachers' conceptions of teaching and learning on their technology acceptance. Interact. Learn. Environ. 2017, 25, 513-527. [CrossRef]

68. Marangunić, N.; Granić, A. Technology acceptance model: A literature review from 1986 to 2013. Univers. Access Inf. Soc. 2015, 14, 81-95. [CrossRef]

69. Huang, F.; Teo, T.; Zhou, M. Factors affecting Chinese English as a foreign language teachers' technology acceptance: A qualitative study. J. Educ. Comput. Res. 2019, 57, 83-105. [CrossRef]

70. Mathews-Aydinli, J.; Elaziz, F. Turkish students' and teachers' attitudes toward the use of interactive whiteboards in EFL classrooms. Comput. Assist. Lang. Learn. 2010, 23, 235-252. [CrossRef] 
71. Xiao, J.; Wang, M.; Jiang, B.; Li, J. A personalized recommendation system with combinational algorithm for online learning. J. Ambient Intell. Humaniz. Comput. 2018, 9, 667-677. [CrossRef]

72. Wang, W.; Curdt-Christiansen, X.L. Teaching Chinese to international students in China: Political rhetoric and ground realities. Asia-Pac. Educ. Res. 2016, 25, 723-734. [CrossRef]

73. Schmid, M.; Brianza, E.; Petko, D. Developing a short assessment instrument for Technological Pedagogical Content Knowledge (TPACK. xs) and comparing the factor structure of an integrative and a transformative model. Comput. Educ. 2020, 157, 103967. [CrossRef]

74. Hew, K.F.; Lan, M.; Tang, Y.; Jia, C.; Lo, C.K. Where is the "theory" within the field of educational technology research? Br. J. Educ. Technol. 2019, 50, 956-971. [CrossRef]

75. Petko, D. Quo vadis TPACK? Scouting the road ahead. In Proceedings of the EdMedia+ Innovate Learning, Online, 23 June 2020 ; Association for the Advancement of Computing in Education (AACE): Waynesville, NC, USA, 2020; pp. $1349-1358$.

76. Mishra, P.; Koehler, M. Technological pedagogical content knowledge: A framework for teacher knowledge. Teach. Coll. Rec. 2006, 108, 1017-1054. [CrossRef]

77. Cochran, K.F.; DeRuiter, J.A.; King, R.A. Pedagogical content knowing: An integrative model for teacher preparation. J. Teach. Educ. 1993, 44, 263-272. [CrossRef]

78. Guo, Z. A Study of Chinese Language Teaching at British Universities: How Communicative Are Chinese Teachers' Methods? Int. J. Chin. Lang. Teach. 2021, 2, 66-86.

79. Rovira-Esteva, S.; Casas-Tost, H.; Morodo, A.; Paoliello, A.; Vargas-Urpi, M. A Multilingual Open Access Database of Resources for Teaching and Learning Chinese as a Foreign Language. 2021. Available online: https://ddd.uab.cat/record/241195 (accessed on 6 February 2022).

80. MOHAMED, O.; WEI, Z.; Media, E. Chinese and Moroccan higher education MOOCs: Rationale, implementation and challenges. Int. J. E-Learn. Educ. Technol. Digit. Media 2017, 3, 31-34. [CrossRef]

81. Wang, C. Design and Implementation of Chinese Pronunciation Automatic Scoring System Based on Speech Recognition. In Proceedings of the International Conference on Cognitive Based Information Processing and Applications, Online, 21 August 2021; Springer: Cham, Switzerland, 2021; pp. 917-921.

82. Li, Y.; Jin, X.; Hu, Q.; Jiang, Q.; Zhao, W.; Oubibi, M. An Empirical Study on the Influence of Co-regulation on Deep Learning under Crowdsourcing Knowledge Construction. In Proceedings of the 2021 IEEE 24th International Conference on Computer Supported Cooperative Work in Design (CSCWD), Dalian, China, 5-7 May 2021; pp. 526-530. 